area. Amongst other facts stated in this paper was the importan one that Coal-seams occurred in Permian strata in the neighbourhoo of Ifton.- -The President remarked upon the enormous time require for the production of the phenomena described by Mr. Davies.--Prot Morris explained the geological and physical features of the district and spoke of the high value of the paper, "Report of the Proceed ings of the Geological Section of the British Association at Edinburgh 1871," by John Hopkinson, F.G.S., etc., one of the deputation fron the Geologists' Association. In this communication the author suc. cinctly stated the more important features of the opening address of the President, Prof. Geikie, and of the many papers read befort Section C, at the meeting at Edinburgh last year, and gave interesting accounts of the two geological excursions under the direction of Prof. Geikie.-J. J. B. Ives, Esq., F.G.S., communicated the interesting fact of an extensive bed of peat occurring under gravel between Finchley and Whetstone.-Fossils from the Glacial deposits of Islington Cemetery were exhibited by Caleb Evans, F.G.S.-At the next ordinary meeting, 2nd February, a paper will be read by the Rev. T. G. Bonney, M.A., F.G.S., "On the Chloritic Marl Deposits of Cambridge."

\title{
OORRFSPONDENOF.
}

\section{THE RAISED BEACH ON PORTSDOWN HILL.}

Sra,-Having been prevented by ill-health from attending the meetings of the Geological Society this winter, I missed the discussion of the President's paper on the above subject, read Dec. 6th, and crave your permission for a brief remark about it.

In my paper on the Weald, in the 27th volume of the Society's Journal, I endeavoured to show that the denudation of the Weald was brought about by a greater upcast of the western or Hampshire area over that of the eastern or Kentish area; the intensity of the forces producing this preponderating western upcast having given rise to the two rectilinear ridges of the Hogsback and Portsdown Hill. I also endeavoured to show, both by description and restoration maps, the way in which, as it appeared to me, the sea was pushed off eastwardly, and confined within an irregular trough, that, under the peculiar geographical conditions of the time, received the drainage of the Thames area in the reversed direction of its present flow, by means of which the Weald valley was denuded.

Although gravels occur at far higher elevations than that occupied by this raised beach, yet objections to the marine origin of such gravels-objections which cannot be settled one way or the other, by reason of the absence of organic remains-are always raised in opposition to the argument for the marine denudation of the southeast of England and Weald valley. Here, however, we have what seems to be admitted as a marine bed, at 300 feet elevation, on one of these two rectilinear ridges whose origin I thus have endeavoured to trace, and connect with the general marine denudation of the 
south-east. Three hundred feet would not only cover the major part of the Weald with the sea, but would also convert the south-east of England into an archipelago, in which the extent of the land-area would be intermediate between that shown in my restoration-map No. I., and that shown in No. II. ; and it is to the period intermediate between these two restorations that $I$ have assigned the upthrow of Portsdown Hill and the Hogsback.

The President connects the bed in question with the Brighton raised-beach; and if that connexion be well founded, we have this preponderance of the westerly upcast shown to the extent of nearly 300 feet in 40 miles, the Brighton beach being but little above the sea-leviel.

Starles V. Wood, jun.

\section{CIRQUES AND TALUSES.}

Srr,-The paper on Cirques and Taluses in your last number (p.10), wherein my friend Mr. Fisher notices my theory of the formation of Cirques, seems to call for a few remarks on my part. I feel much indebted to him for the kind manner in which he has expressed his divergence of opinion from myself, and regret that, notwithstanding his able plea for glaciers, I must hold to my words.

He concludes that " a cirque, though not excavated by a glacier, is strictly a glacial phenomenon," while I have stated that, "the completeness of the cirque as a whole forbids us-unless we assign it entirely to glacial action-to suppose that it was more than slightly altered by this." To some extent the difference between us is more a question of words than anything else. I hold that atmospheric and stream action made the cirques; Mr. Fisher thinks that, by whatever agent they were made (probably as I have suggested), a glacier cleaned out the rubbish which must have accumulated in them prior to the Glacial epoch, and that, instead of saying "in not a few corries and cirques the transporting power (of stream) can hardly keep pace with the excavatory," I should have said can not keep pace. With regard to the former point, the glacier would most probably clear out the cirques, but I do not know that there is any evidence to show that they were formerly more choked up than they now are. As to the latter, I used the "word of doubtful signification" deliberately; hecause, although I think that not seldom the débris is on the whole accumulating, the increase is so slight as to be almost imperceptible; so that any unusually heavy storm may in an hour wash away the accumulation of a century. Débris strewn over iceworn slopes below the cliffs and screes masking the junction between these two (as in the case referred to) do not necessarily prove that the cirque is filling up; they only mark a stage in the quarry work of nature. The sawing of streamlets, aided by frost, etc., brings down the stone from the face of the cliff in fragments of various sizes; these, often broken smaller by their fall, lie on the slopes below, subjected to the same action of rain, heat, frost, until they are reduced to yet smaller fragments or even to fine dust, or are swept away by some swelling of 